\title{
Amerindians in the face of Covid-19
}

Current state of affairs and press review

\section{Paul Codjia and Raphaël Colliaux}

\section{(2) OpenEdition}

\section{Journals}

Electronic version

URL: https://journals.openedition.org/jsa/19797

DOI: 10.4000/jsa. 19797

ISSN: 1957-7842

This article is a translation of:

Les Amérindiens face au Covid-19 - URL : https://journals.openedition.org/jsa/19674 [fr]

Other translation(s):

Los Amerindios frente al Covid-19 - URL : https://journals.openedition.org/jsa/19799 [fr]

Os povos indígenas e o Covid-19 - URL : https://journals.openedition.org/jsa/19804 [pt]

\section{Publisher}

Société des américanistes

\section{Printed version}

Date of publication: 30 September 2021

Number of pages: 317-321

ISSN: 0037-9174

\section{Electronic reference}

Paul Codjia and Raphaël Colliaux, "Amerindians in the face of Covid-19", Journal de la Société des américanistes [Online], 107-1 | 2021, Online since 30 September 2021, connection on 03 September 2022. URL: http://journals.openedition.org/jsa/19797 ; DOI: https://doi.org/10.4000/jsa. 19797

This text was automatically generated on 3 September 2022

All rights reserved 


\title{
Amerindians in the face of Covid-19
}

\author{
Current state of affairs and press review
}

Paul Codjia and Raphaël Colliaux

1 We are pleased to announce here a list of online works of various kinds (scientific texts, newspaper articles, videos, photo collections) that bear witness to the living conditions of Amerindians during this worldwide health crisis. The list, still under construction and with items grouped into sections, can be accessed via the website of the Société des américanistes (www.americanistes.org), which is inaugurating a column devoted to this topic. Though because of their personal research interests the compilers have thus far concentrated on the Amazon basin, this reference list will eventually include writings and other materials that describe the situations of Amerindians throughout the Americas in the time of the pandemic. 
Fig. 1 - A doença do Covid-19, Jaime Diakara'

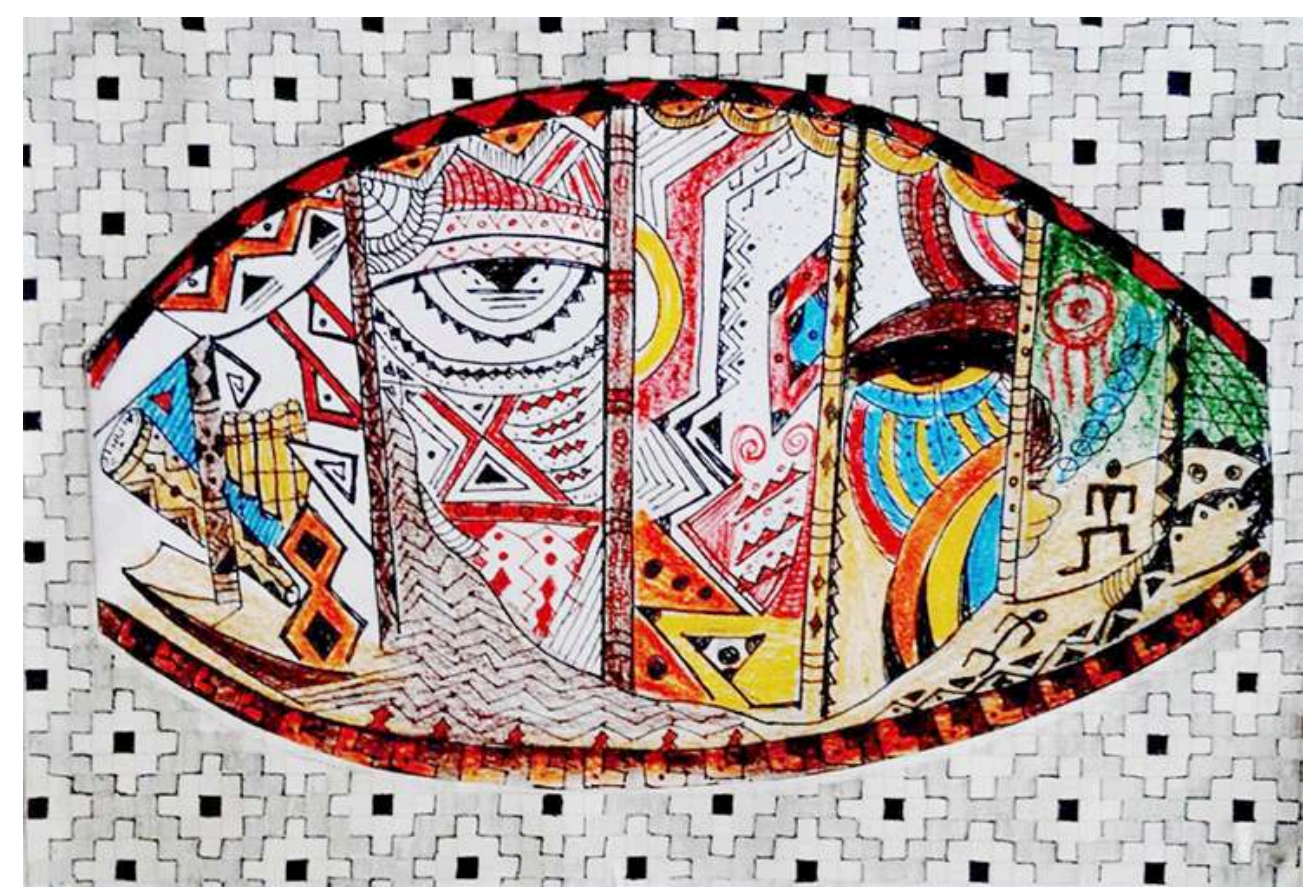

$* * *$

2 As early as April-May 2020, a number of academics, journalists, Amerindian political leaders, and NGO activists set out to document the impact of the Covid-19 pandemic on the indigenous populations in the Amazon basin. Whether in journal articles, scientific blogs, or popular magazines, all have sounded the alarm, each in their own way, on the health, social, economic, environmental, political, and anthropological consequences of the SARS-CoV-2 virus in the Amazon lowlands. We would like to applaud here their rapid response and the efforts they have already made not only to investigate but also to analyze and reflect on findings in such a short time, in order to expose the dramatic situations in which these populations often find themselves. The pandemic has only added to a context of precarious land tenure, failing health systems, and state policies that disfavor indigenous rights. The case of Brazil under Bolsonaro's regime is certainly the most tragic.

For this non-exhaustive list, we have gathered texts that offer a fairly wide panorama of the diverse situations and difficulties that Amazonian peoples are facing in these times of Covid-19. Our goal is to allow readers to identify problems, to open research perspectives, and to continue to document, render visible, and support lowland indigenous peoples. Since we are restricted to virtual meetings to avoid acting as vectors of the virus, a large number of researchers who specialize in this region are limited to sporadic exchanges with their contacts and friends in the field, and to gleaning bits of information from social networks or specialized media. The list presented here is meant to facilitate investigations, which is why a survey of current scientific literature on Covid-19 in the Amazon basin appears alongside a press review, and also why the list includes links to raw documents such as health instructions translated into Amerindian languages. We start with scientific articles and special issues of journals, which are followed by journalistic pieces, all under thematic headings. 
During this period of isolation due to the pandemic, the very methods of ethnographic research are being tested, especially among non-native researchers. And this is perhaps an important lesson to be learned from this yet-incomplete bibliography: the current health context seems to be accelerating collaborations in the analysis and even in the writing up itself between academics and representatives of indigenous groups. Even better, a substantial number of the articles listed are written by native researchers, especially those related to the Brazilian Amazon. In spite of lock-downs, communication channels have allowed for ongoing monitoring and collection of information (as exemplified by the Facebook page https://www.facebook.com/groups/coronamazon/, administered by Émilie Stoll and moderated by Ricardo Fohlhes and Élise Capredon), and also for sharing ideas and collaborative reflection with indigenous contacts in the field, who are often political leaders.

5 In addition to providing descriptions-often in the form of numerical data-of the epidemic, the articles point to several lines of study. First, a central theme that appears in virtually all the texts is the relationship between indigenous groups, the state, and health systems. The articles highlight the inability of the governments to respond to the health needs of indigenous populations due not only to inequitable health policies, but also-which is probably even more serious-to ignorance of social realities, such as infrastructure, and of Amerindian health practices. The words used by native contacts to describe the situation are quite strong, ranging from the semantic field of abandonment in Andean countries to that of absence of government in Brazil, where indigenous people have no illusions about the Bolsonaro regime's intentions towards them. Lacking adequate institutional resources to protect their bodies, Amerindians are choosing to protect their territories.

6 There is clear reaffirmation of claims to territorial sovereignty, which, paradoxically, is reinforced by recommendations in Andean states that indigenous groups close and control access to their lands. As noted by Irène Bellier in several items in the list, the health of people and the "health" of territories are closely connected, a connection that is primarily related to nourishment. It is regularly noted that food produced on indigenous land is one of the conditions for maintaining good health, as opposed to food originating in cities, where the coronavirus runs rampant. The will to protect one's territory is particularly apparent in struggles to curb logging and gold-mining activities. Along these lines, and perhaps with a hint of irony, Gregorio Mirabal, the coordinator of Coordinadora de Organizaciones Indígenas de la Cuenca Amazónica (COICA), recently declared: "Tenemos que hacer un proceso de vacunaciones en todos los territorios de la cuenca amazónica con esa vacuna que se llama 'gobernanza territorial indígena' $y$ que es lo único que nos puede salvar" ("We must carry out vaccinations in all the territories of the Amazon basin with that vaccine called 'indigenous territorial governance' and that is the only thing that can save us").

7 Strikingly, some Amerindian claims to land and autonomy have gained legitimacy in the vacuum left by the state. At the same time, indigenous peoples appear to have been hit hard by a spectacular upsurge in extractive activities, including, among others, logging, oil drilling, and mining. In Peru, as early as May 2020, a series of laws exonerated certain economic sectors from restrictive environmental regulations, and weakened mechanisms for consulting the public before carrying out such activities. The pandemic could thus potentially augur a double movement: first, a decline in the power of the public, and, second, a restructuring of the private sector under many guises, whose 
activities are often informal, sometimes even criminal. The murders of Amerindian leaders and environmental activists, which have proliferated since the beginning of the pandemic in the Peruvian and Colombian Amazon regions, are a tragic reminder that indigenous lands are coveted more than ever.

8 Nevertheless, the acceptability of such activities in indigenous lands is debated even within indigenous groups, especially since the health crisis has at times cut off substantial revenue. We have seen the pandemic exacerbate old problems, among them the actions of Protestant evangelical missionaries. Several sources suggest that Protestant pastors take advantage of fear of the virus to consolidate their influence and to build new momentum in proselytizing.

more worrisome among indigenous groups in socalled "voluntary isolation," where certain religious factions might be tempted to force contact in the wake of the profound reconfiguration of local political dynamics, the emerging face of which is still barely perceptible. Since at least the 16th century, Amerindians of the Amazon have used distancing and isolation strategies to protect themselves from immunological dangers (smallpox, measles, flu) connected to European colonization, but also perhaps from zoonoses potentially present in the tropical forest (see Stephen Rostain's article ${ }^{2}$ ). In many cases, this voluntary isolation has redoubled over the years, as new forms of colonization have appeared and intensified (evangelical and Catholic proselytizing, industrial agriculture, oil exploitation, gold-mining, illegal logging, drug traffic, tourism), in the face of which local public institutions are powerless or perhaps even complacent. Since, given their long self-isolation, these Amerindian communities remain extremely vulnerable to viral and other infectious diseases, Covid-19 constitutes a serious danger that numerous observers are striving to document.

This theme also invites more serious reflection on the notion of "social isolation." Recent events have brought about a reversal in the perception of the practice, heretofore considered as primitive and anachronistic, associated with Amerindians hostile to modernity. On the contrary, global measures taken to counter Covid-19 reveal, as in a mirror, how these Amerindian lifestyles emerged directly from the social and politicaland viral-contexts that these populations have faced; their choice to protect themselves through social isolation is now shared by state governments. In this way, the literature shows the perpetuation, the renaissance, and even the legitimation of voluntary isolation strategies in this region of the world and beyond.

11 These texts do not just paint gloomy pictures of the current situation. They also bring to light the extraordinary organizational, political, and health resources that Amerindians are mobilizing to protect themselves and to cope with and stem the tide of the virus. Indigenous initiatives are flourishing that promote local medical knowledge and practices and that call for state health policies that are truly intercultural.

The epidemic thus appears to be a "total social fact" in a postcolonial context, a nexus where even divergent funeral practices and eschatological ideas rub against each other. For instance, Bruce Albert alerts us to the tragedy befalling the Yanomami, deprived of the bodies of their deceased kin, which are incinerated by health workers to prevent contagion. In this way, the reference list unveils an "epidemic situation"-to paraphrase Georges Balandier-that brings together more than ever all the local actors: Amerindian populations of diverse lifestyles, various colonizers, private companies, and public institutions, with a viral agent to boot. ${ }^{3}$ 


\section{Reference list available on the website of the Société des américanistes}

13 http://www.americanistes.org/en/2021/05/30/amerindians-in-the-face-of-covid-19/

\section{Section headings}
1. Scientific works
2. Amerindian chronicles
3. Indigenous therapeutic practices
4. Urban Amerindians and the coronavirus
5. Extractive industries and the pandemic
6. Evangelical missionaries
7. Amerindian populations in "voluntary isolation"
8. Photojournalism portfolios
9. Institutional information
10. Instructions for virus prevention in indigenous languages

\section{NOTES}

1. Jaime Diakara is an anthropologist and Desana painter (Tukano language group, Brazilian Amazon). The author created this painting after being affected by the disease. He wanted to express the symptoms he had experienced. He explains that the left-hand side represents the infection with SARS-CoV-2 and how the virus took over his body. The right-hand side shows the figures of his father and his ancestors who, with their knowledge of medicinal plants, helped him to overcome the disease.

2. «Amazonie, une histoire sans geste barrière " [online], December 16, 2020, https:// covidam.institutdesameriques.fr/amazonie-une-histoire-sans-geste-barriere/, accessed 25/05/2021.

3. Translated by Margaret Buckner. 


\section{AUTHORS}

PAUL CODJIA

McGill University - Fondation Fyssen - IFEA, member of the Amaz project (ANR-17-CE41-0013)

\section{RAPHAËL COLLIAUX}

IFEA - PUCP - Fondation Fyssen, member of the Amaz project (ANR-17-CE41-0013) 